\title{
実験ワンポイント
}

\section{広い密度・圧力領域における超臨界流体に対する 精密密度測定の新しい方法}

New Method for Precise Measurement of Density of Supercritical Fluid over a Wide Range of Pressure

\section{吉田 健}

Ken YOSHIDA
松林 伸幸

Nobuyuki MATUBAYASI Masaru NAKAHARA*

\begin{abstract}
We have developed two methods to determine the density of supercritical fluid sealed in a tube. One is the massvolume method that is applicable to higher densities than $0.07 \mathrm{~g} \mathrm{~cm}^{-3}$ at $400^{\circ} \mathrm{C}$ when the fluid is water. In this method, the mass of the sample and the bore volume of the tube are determined precisely. The other is the chemical shift method, which takes advantage of the temperature dependence of the chemical shift and the $P V T$ data. The latter is especially powerful at lower densities.

[supercritical water, density, mass-volume method, chemical shift method, NMR, sealed-tube method, equation of state, self-diffusion]
\end{abstract}

1.はじめに

超臨界流体中では，常温常圧下と異なり，密度 （圧力）を連続的かつ自由に変化させることができ る。超臨界流体中の構造・ダイナミクス・化学反応 を研究するときは, 圧力よりも密度の関数として考 察すると，解釈がより明確になる場合が多い[1]。 最近, 我々は高温高圧高分解能多核 NMR 装置を開 発することに成功した[2]。この装置では, 石英管 に封じ込めた試料を加熱することで, 高温高圧状態 を実現した（sealed-tube 法）。このとき，石英管内 の試料密度を精確に制御・決定する方法を 2 種類提 唱した。1つは, 質量-体積法[2] で, 試料容器内の 体積と試料の質量の精密測定によるものである。こ の方法の適用範囲は, $400^{\circ} \mathrm{C}$ 水の場合, $0.07 \mathrm{~g} / \mathrm{cm}^{3}$ 以上（16 MPa 以上）である。もう 1 つは，化学シ フト法[3]で, 化学シフトを用いて求めた転移温度 $T_{\mathrm{t}}$ と $P V T$ デー夕を併用する。1 成分系においては, ギブスの相律により密度は一意に決定される。この 方法は, 質量一体積法で不可能な超低密度（水にお いて $0.07 \mathrm{~g} / \mathrm{cm}^{3}$ 以下）で特に有効である。これらの 方法は, 水のみならず他の様々な超臨界流体に, 特
別な装置を新たに導入することなく適用可能である。 適用例は，原論文を参考にされたい $[2,3]$ 。

\section{2. 質量一体積法}

石英管に封じ込めた超臨界水の密度は，導入した 水の質量を石英管内の空洞の体積で割ったもので与 えられる。水の質量は，管中に水を含むときと含ま ないときの石英管の質量の差として求められる。石 英管内の空洞の体積は, 石英管の全体積と石英その むのの体積の差として求められる。管の全体積は, 管全体を液体に沈めたときの体積変化で測定できる。 この方法の精度は, 管全体の体積測定の精度（1\%) で決定される。石英そのものの体積は, 石英の質量 と密度によって決定する。石英の質量測定の誤差は, $1.0 \mu \mathrm{g}$ の精度を持つ超精密電子天科（Mettler Toledo UMX-2）を用いれば， $0.1 \%$ 未満である。石英の密 度は, 石英片の質量と, 石英片を液体に沈めたと きの体積変化とから決定できる。試料が超臨界水 である場合, 小さな体積で測定可能な密度は $0.07 \mathrm{~g} / \mathrm{cm}^{3}$ 以上に限定される。

\section{干611-0011 京都府宇治市五ケ庄 京都大学化学研究所}

Institute for Chemical Research, Kyoto University, Uji, Kyoto 611-0011

*Electronic address: nakahara@scl.kyoto-u.ac.jp 


\section{3. 化学シフト法}

上述の質量-体積法の精度は, $0.01-0.02 \mathrm{~g} / \mathrm{cm}^{3}$ 程 度である。そこで, 最近我々が開発したのが, 低密 度で有効な化学シフト法である。この際必要となる 精密な $P V T$ デー夕は, 水の場合は, IAPWS により 提供されている $[4]$ 。我々は, この方法により, 水 の自己拡散係数のゼロ密度極限值を求めることに成 功した[3]。

石英管内（閉鎖系）における超臨界水（1 相）の 密度は, 転移温度 $T_{\mathrm{t}}$ (気液界面が消失する温度) に より一意に決定され, 臨界密度未満においては $T_{\mathrm{t}}$ での気液共存曲線上の気体（蒸気）側の密度と等し い。 $T_{\mathrm{t}}$ は化学シフトの温度依存性から決定できる。 Fig. 1 に, 超臨界状態（1 相）に拈いて密度が $0.0041 \mathrm{~g} / \mathrm{cm}^{3}$ になる試料の ${ }^{1} \mathrm{H}$ 化学シフト $\delta$ の $T_{\mathrm{t}}$ 近 傍における温度依存性を示す。 $\delta$ は極大值を持ち, その時の温度が $T_{\mathrm{t}}$ である。これは, $\delta$ と正の相関を 持つ水素結合の強さの温度依存性が, $T_{\mathrm{t}}$ 前後で逆転 するからである。 $T_{\mathrm{t}}$ は $1{ }^{\circ} \mathrm{C}$ の精度で決定された。

Fig. 2 に, 質量-体積法と化学シフト法の各々で密 度を決定したときの水の自己拡散係数 $D$ を, $\rho D / \sqrt{T}$ の $\rho$ に対するプロットで示した。ここで, $\rho$ は密度, $T$ は絶対温度である。2つの方法でのデー 夕の整合性が，双方の信頼性を示している。

化学シフト法は，精密な $P V T$ データの得られて

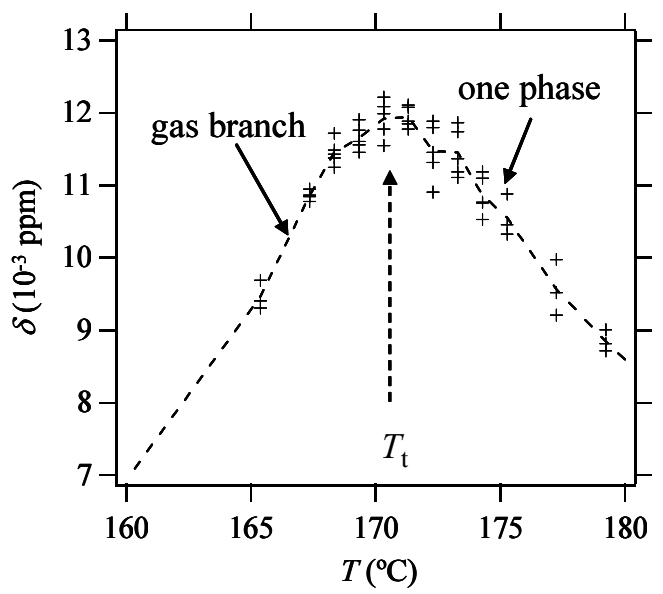

Fig. 1. The chemical shift $\delta$ plotted against temperature for a water sample whose density is $0.0041 \mathrm{~g} / \mathrm{cm}^{3}$ at supercritical states. The $\delta$ for the gas branch of the liquid-gas coexistence curve at $146^{\circ} \mathrm{C}\left(0.0023 \mathrm{~g} / \mathrm{cm}^{3}\right)$ is set to zero. The dashed line indicates the average of the repetitions.

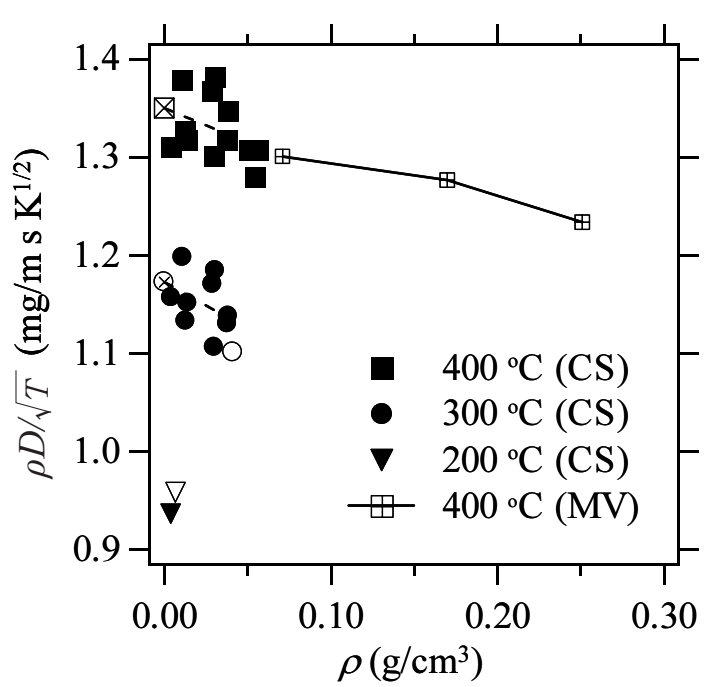

Fig. 2. The product of the self-diffusion coefficients of water and the density divided by square root of the temperature, $\rho D / \sqrt{T}$, plotted against the density at 200,300, and $400^{\circ} \mathrm{C}$. MV and CS in the figure stand for the mass-volume method and the chemical shift method, respectively, for the $\rho$ determination. The open symbols indicate the values on the gas-branch of the liquid-gas coexistence curve. The dashed line is linearly fitted to the experimental values and the crossed symbols indicate the values extrapolated to the zerodensity limit.

いる系であれば適用可能である。例えば，ベンゼン は詳細な $P V T$ データが得られている[5]。最近我々 は，低密度超臨界ベンゼンにおいて化学シフト法に よる密度決定に成功した[6]。ベンゼンの場合も， $T_{\mathrm{t}}$ は $1{ }^{\circ} \mathrm{C}$ の精度で決定可能である。

\section{参考文献}

[1] 例えば, 高圧力の科学と技術, 16, 86-136 (2006), およびそれらの引用文献.

[2] K. Yoshida, C. Wakai, N. Matubayasi, M. Nakahara: J. Chem. Phys. 123, 164506 (2005).

[3] K. Yoshida, N. Matubayasi, M. Nakahara: J. Chem. Phys. 125, 074307 (2006).

[4] Release on the IAPWS Formulation 1995 for the Thermodynamic Properties of Ordinary Water Substances for General and Scientific Use, URL: http://www.iapws.org.

[5] R. D. Goodwin: J. Phys. Chem. Ref. Data, 17, 1541 (1988).

[6] K. Yoshida, N. Matubayasi, M. Nakahara (in preparation).

[2006 年 9 月 21 日受理] C을 2006 日本高圧力学会 